\title{
Prevention of Clostridium difficile infection in hamsters using a non-toxigenic strain
}

\author{
Prevenção da infecção por Clostridium difficile em hamsters usando uma estirpe não toxigênica
}

\author{
Carlos Augusto de Oliveira Júnior ${ }^{I^{*}}$ Rodrigo Otávio Silveira Silva ${ }^{\mathrm{I}}$ Amanda Nádia Diniz \\ Prhiscylla Sadanã Pires ${ }^{I}$ Francisco Carlos Faria Lobato ${ }^{I}$ Ronie Antunes de Assis ${ }^{I I}$
}

\section{ABSTRACT}

The present study aimed to evaluate five nontoxigenic strains of Clostridium difficile (NTCD) in vitro and to select one strain to prevent $\boldsymbol{C}$. difficile (CDI) infection in hamsters (Mesocricetus auratus). The NTCD strains were evaluated for spore production in vitro, antimicrobial susceptibility and presence of antimicrobial resistance genes. Approximately $10^{7}$ spores of the selected strain (Z31) were administered by esophageal gavage in hamsters pretreated with $30 \mathrm{mg} \mathrm{kg}^{-1}$ of clindamycin. The challenge with a toxigenic strain of $\boldsymbol{C}$. difficile was conducted at 36 and $72 \mathrm{~h}$, and the animals were observed for 28 days. The NTCD strain of $\boldsymbol{C}$. difficile (Z31) was able to prevent $C D I$ in all animals that received it.

Key words: diarrhea, Clostridium difficile-associated diseases, colitis.

RESUMO

O presente trabalho objetivou a avaliação in vitro de cinco estirpes não toxigênicas de Clostridium difficile (NTCD) $e$ seleção de uma delas para prevenção de infecção por $\boldsymbol{C}$. difficile (CDI) em hamsters (Mesocricetus auratus). As estirpes NTCD foram avaliadas quanto à produção de esporos in vitro, sensibilidade antimicrobiana e presença de genes de resistência a antimicrobianos. Aproximadamente $10^{7}$ esporos da estirpe selecionada (Z31) foram administrados por gavagem esofágica em hamsters previamente tratados com $30 \mathrm{mg} \mathrm{kg}^{-1}$ de clindamicina. $O$ desafio com uma estirpe toxigenica de $\boldsymbol{C}$. difficile ocorreu nos tempos experimentais 36 e $72 \mathrm{~h}$, e os animais foram observados por 28 dias. A estirpe NTCD de C. difficile (Z31) foi capaz de prevenir a CDI em todos os animais que a receberam.

Palavras-chave: diarreia, doenças associadas à Clostridium difficile, colite.

\section{INTRODUCTION}

Clostridium difficile (CDI) infection is a disease that affects several species, including humans, swine and equines, with different clinical presentations (SILVA et al., 2013a). In swine, the disease affects one- to seven-day-old animals and is subclinical, resulting in decreased body development and reduction of the zootechnical indexes of the swine farm (SONGER \& ANDERSON, 2006). Surveys conducted in Brazil suggested a high prevalence of $\boldsymbol{C}$. difficile in neonatal piglets, emphasizing the increased importance of this disease in this age group (SILVA et al., 2011; CRUZ JUNIOR et al., 2013). In addition, in equines, CDI affects young and adult animals, with pre-antimicrobial therapy being one of the main predisposing factors for disease development (BÅVERUD et al., 2003). Although scarce, studies show a higher frequency of $\mathrm{CDI}$ in veterinary hospitals than in commercial stud farms (SILVA et al., 2013a).

CDI control is limited to treatment of sick animals and general management measures; thus far, no vaccine to control the disease is commercially available (SILVA et al., 2013a). A possible alternative to CDI prevention would be the use of non-toxigenic strains of $\boldsymbol{C}$. difficile (NTCD) as competitive exclusion agents, as they do not have the genes responsible for the production of toxins that cause the disease, but retain the

IEscola de Veterinária, Universidade Federal de Minas Gerais (UFMG), Av. Antônio Carlos, 6627, 31270-901, Belo Horizonte, MG, Brasil.

E-mail: carlos.dirgel@hotmail.com. *Corresponding author.

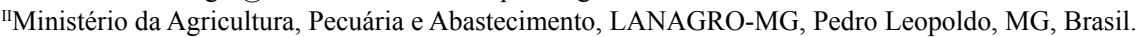
Received 03.27.15 Approved 10.20.15 Returned by the author 02.07.16 CR-2015-0454.R2 
colonization capacity (SAMBOL et al., 2002). However, the use of NTCD requires careful analysis and previous testing in experimental animal models prior to their use in the target. Furthermore, due to the geographical variability between different PCR ribotypes, it is more appropriate to use strains isolated from the same region in which they will be tested (JANEZIC et al., 2012). Therefore, the aim of the present study was to evaluate five NTCD strains isolated in Brazil and to select one strain that will then be assessed for its capacity to prevent CDI development in hamsters.

\section{MATERIALS AND METHODS}

Strains

Five NTCD strains from the bacteria collection of the Laboratório de Anaeróbios of the Veterinary School of the Federal University of Minas Gerais (Universidade Federal de Minas Gerais - UFMG) were used in the present study. The strains were isolated from healthy animals in Brazil, subjected to DNA thermal extraction $\left(90^{\circ} \mathrm{C}\right.$ for $\left.20 \mathrm{~min}\right)$ and characterized as nontoxigenic $\left(\mathrm{A}^{-} \mathrm{B}^{-} \mathrm{CDT}^{-}\right)$by PCR (SILVA et al., 2011). The strains did not produce the $A / B$ toxins by cell serum neutralization (SILVA et al., 2013b). The five strains were also previously ribotyped according to JANEZIC \& RUPNIK (2010) (Table 1). A toxigenic strain $\left(\mathrm{A}^{+} \mathrm{B}^{+} \mathrm{CDT}\right.$, $\mathrm{PCR}$ ribotype 012) was used for disease induction; the strain belongs to the same bacteria collection as the other five NTCD strains and was previously isolated from a swine with $\mathrm{CDI}$ confirmed by A/B toxin detection.

Table 1 - Details of non-toxigenic $\boldsymbol{C}$. difficile strains (NTCD) with regard to origin, ribotype, spore production in vitro, antimicrobial resistance profile and presence of resistance genes.

\begin{tabular}{|c|c|c|c|c|c|c|}
\hline Strain & $\begin{array}{l}\text { Species of strain } \\
\text { origin }\end{array}$ & Ribotype & $\begin{array}{l}\log _{10} \text { of spore counts } \\
\text { in vitro }\end{array}$ & \multicolumn{2}{|c|}{$\begin{array}{l}\text { Minimal Inibitory Concentration } \\
\text { (MIC) }\left(\mu \mathrm{g} \mathrm{mL}^{-1}\right):^{*}\end{array}$} & $\begin{array}{c}\text { Antimicrobial resistance } \\
\text { genes }\end{array}$ \\
\hline $\mathrm{H} 4$ & Swine & 053 & $\begin{array}{c}4.72 \pm 0.03 \\
\mathrm{~d}\end{array}$ & $\begin{array}{l}\text { Cl: } 32.0 \\
\text { Li: } 64.0 \\
\text { Ox: } 8.0 \\
\text { Ту: } 2.0\end{array}$ & $\begin{array}{l}\text { Er: } 1.0 \\
\text { Me: } 0.25 \\
\text { Pe: } 0.5 \\
\text { Va: } 0.25\end{array}$ & - \\
\hline EQ3 & Equine & 053 & $\begin{array}{c}5.42 \pm 0.05 \\
\mathrm{c}\end{array}$ & $\begin{array}{l}\text { Cl: } 32.0 \\
\text { Li: } 8.0 \\
\text { Ox: } 4.0 \\
\text { Ty: } 2.0\end{array}$ & $\begin{array}{l}\text { Er: } 1.0 \\
\text { Me: } 0.25 \\
\text { Pe: } 0.5 \\
\text { Va: } 0.25\end{array}$ & $b c r A, b c r B$ \\
\hline $\mathrm{Z} 31$ & Canine & 009 & $\begin{array}{c}6.68 \pm 0.03 \\
\text { a }\end{array}$ & $\begin{array}{l}\text { Cl: } 64.0 \\
\text { Li: } 64.0 \\
\text { Оx: } 8.0 \\
\text { Ту: } 2.0\end{array}$ & $\begin{array}{l}\text { Er: } 0.5 \\
\text { Me: } 0.25 \\
\text { Pe: } 0.5 \\
\text { Va: } 0.25\end{array}$ & tetM \\
\hline $\mathrm{R} 1$ & Canine & 009 & $\begin{array}{c}6.21 \pm 0.06 \\
b\end{array}$ & $\begin{array}{l}\text { Cl: } 32.0 \\
\text { Li: } 4.0 \\
\text { Ox: } 2.0 \\
\text { Ty: } 2.0\end{array}$ & $\begin{array}{l}\text { Er: } 0.5 \\
\text { Me: } 0.25 \\
\text { Pe: } 0.25 \\
\text { Va: } 0.25\end{array}$ & $b c r B$ \\
\hline S8 & Canine & 009 & $\begin{array}{c}5.37 \pm 0.04 \\
\mathrm{c}\end{array}$ & $\begin{array}{l}\text { Cl: } 32.0 \\
\text { Li: } 4.0 \\
\text { Ox: } 8.0 \\
\text { Ty: } 2.0\end{array}$ & $\begin{array}{l}\text { Er: } 0.5 \\
\text { Me: } 0.25 \\
\text { Pe: } 0.25 \\
\text { Va: } 0.25\end{array}$ & $b c r A$ \\
\hline
\end{tabular}

Legend: Cl: Clindamycin; Er: Erythromycin; Li: Lincomycin; Me: Metronidazole; Ox: Oxytetracycline; Pe: Penicillin; Ty: Tylosin; Va: Vancomycin.

${ }^{*}$ Breakpoints $\left(\mu \mathrm{g} \mathrm{mL}^{-1}\right)$ : Clindamycin: 32.0; Erythromycin: 2.0; Lincomycin: 16.0; Metronidazole: 2.0; Oxytetracycline: 16.0; Penicillin: 2.0; Tylosin: 16.0; Vancomycin: 2.0.

Obs. 1: Different letters indicate different means by Student's t test $(\mathrm{P}<0.05)$.

Obs. 2: Bold values means that the strain is resistant to the antimicrobial. 
Antimicrobial susceptibility and detection of antibiotic resistance genes

After sample reconstitution, the antimicrobial susceptibility profiles to clindamycin, erythromycin, lincomycin, metronidazole, penicillin, oxytetracycline, tylosin and vancomycin (SigmaAldrich, EUA) were determined using the minimum inhibitory concentration (MIC) method in Brucella agar plates enriched with 5\% horse blood and antimicrobial concentrations ranging from 0.25 to $256.0 \mathrm{mg} \mathrm{L}^{-1}$, as recommended by the Clinical and Laboratory Standards Institute (CLSI, 2011). Macrolide-lincosamide-streptogramin B resistance determinants $(\mathrm{erm} B)$, oxytetracycline resistance genes (tet $M)$, and bacitracin resistance genes ( $b c r A$, $b c r B, b c r C$ and $b c r R$ ) were determined by PCR, as previously described by SPIGAGLIA et al. (2007) and CHARLEBOIS et al. (2012).

Spore production and strain selection

Six batches of spores per $\boldsymbol{C}$. difficile strain were produced as described by SILVA et al. (2014a). The concentration of each batch was determined by plating on blood agar enriched with $0.1 \%$ taurocholate. Spore concentrations were converted into base10 logarithm, means and standard deviations were calculated, and means were compared using Student's $\mathrm{t}$ test $(\mathrm{P}<0.05)$ (GraphPad Prism 6, USA). High production of spores in vitro, antimicrobial resistance profiles and/or presence of resistance genes were considered in order of importance for strain selection.

Animal experimentation: groups and treatments Thirty adult Syrian hamsters (Mesocricetus auratus) were randomly separated into five groups of six animals (I to V). At time 0 , all animals received $30 \mathrm{mg} \mathrm{kg}^{-1}$ of clindamycin intramuscularly. After $24 \mathrm{~h}$, animals in groups II and III received $10^{7}$ UFC spores of the NTCD strains by esophageal gavage. Animals in groups II and IV were challenged with $10^{8}$ spores of a $\boldsymbol{C}$. difficile toxigenic strain at $36 \mathrm{~h}$, while animals in groups III and V were challenged with the same spore concentration at $72 \mathrm{~h}$. Animals in group I were only subjected to gavage with $0.85 \%$ saline at 24 , 36 and $72 \mathrm{~h}$. The animals were observed for 28 days, and those who survived the experimentation period were euthanized with $100 \mathrm{mg} \mathrm{kg}^{-1}$ of pentobarbital intravenously (Figure 1).

Fecal pellets were collected daily from each animal in microtubes containing saline for the isolation and detection of $\boldsymbol{C}$. difficile toxins (SILVA et al., 2011). After natural death or euthanasia, the animals were necropsied, the colon was fixed in formalin for histopathology analysis, and the intestinal content was collected for isolation of $\boldsymbol{C}$. difficile and toxins identification by a commercial enzyme-linked immunosorbent assay (ELISA) kit (Techlab, USA) according to the manufacturer's

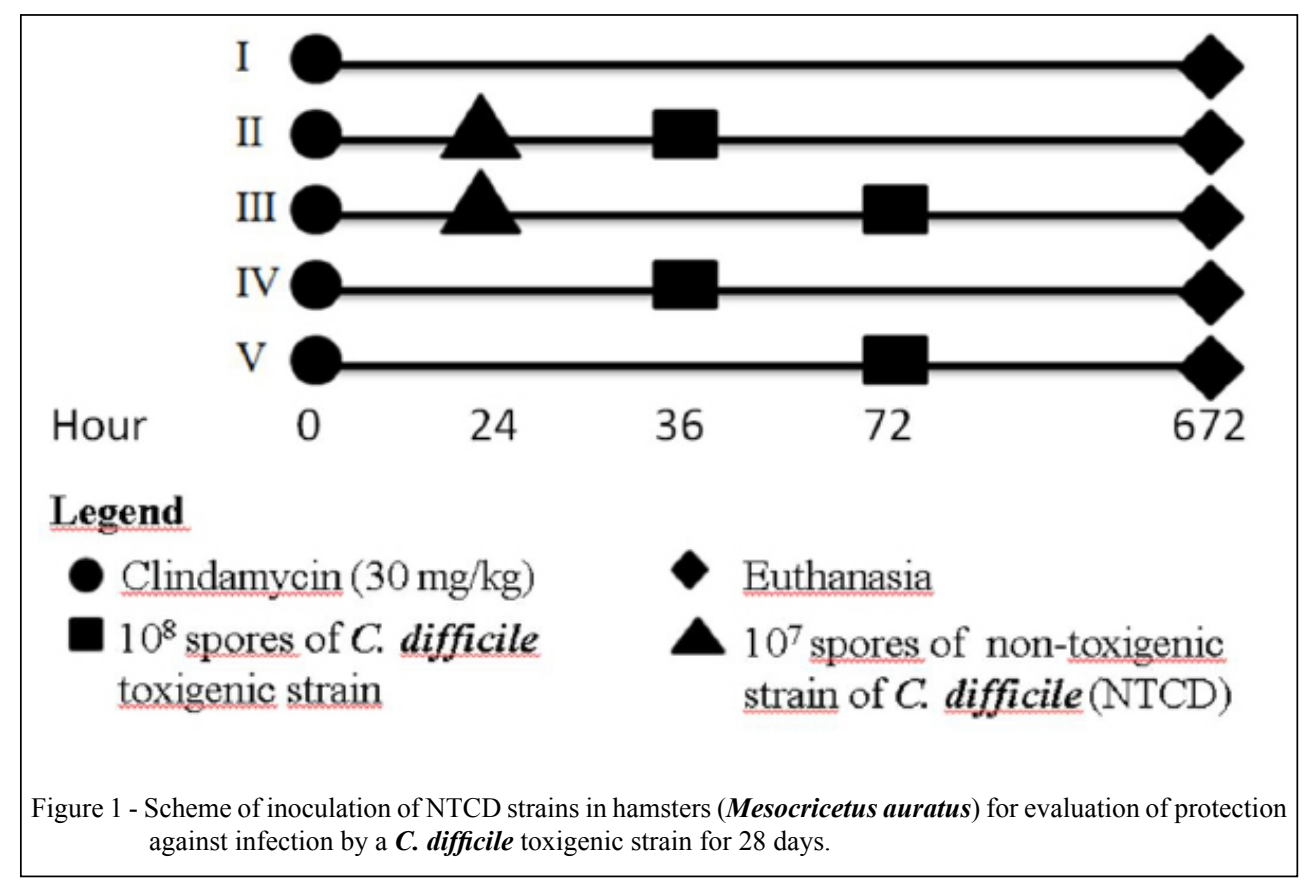

Ciência Rural, v.46, n.5, mai, 2016. 
recommendation. The intestines of euthanized animals were analyzed by electron microscopy, as described by HUMPHREY et al. (1979). To evaluate the capacity of the tested strain to prevent CDI development in hamsters, a Kaplan-Meier survival chart was constructed and analyzed using the Mantel-Cox test (GraphPad Prism 6, USA).

\section{RESULTS AND DISCUSSION}

All details of the five $\boldsymbol{C}$. difficile strains used in the present study are shown in table 1. Although the ribotype 053 of $\boldsymbol{C}$. difficile is not commonly described in the literature, two recent studies performed in Brazil isolated the NTCD strains ribotype 053 in coatis (Nasua nasua) and wild carnivores, confirming the presence of this ribotype in different species in the country (SILVA et al., 2014b; SILVA et al., 2014c). The NTCD strains of ribotype 009 have been isolated in studies with humans and healthy animals in different geographic regions (KEEL et al., 2007; KOENE et al., 2011; JANEZIC et al., 2012). An ongoing study in Brazil has shown that strains 009 and 053 are the most common in the country among NTCD strains and that they have been isolated in different species, including swine, a fact that makes them relevant for the goal of the present study. Other studies that used NTCD strains to prevent CDI in hamsters selected the M3, M23 and $\mathrm{T} 7$ types after molecular typing using restriction endonuclease analysis (REA) (SAMBOL et al., 2002; MERRIGAN et al., 2009; NAGARO et al., 2013). There is no well-established correlation between the REA characterization methods and ribotyping. Currently, studies focusing on typing use ribotyping due to the simplicity of the technique and the greater discrimination among strains, which allows better comparisons with and deeper discussion concerning other studies (KILLGORE et al., 2008).

All strains were susceptible to metronidazole, penicillin, tylosin and vancomycin. Metronidazole and vancomycin are the antimicrobials of choice for CDI treatment in humans and equines; few $\boldsymbol{C}$. difficile strains are resistant to these drugs. In contrast, resistance to penicillin and tylosin has been reported in Brazil and other countries (BÅVERUD et al., 2003). Two (40\%) and three (60\%) strains had intermediate susceptibility profiles to erythromycin and oxytetracycline, similar to what was reported by SILVA et al. (2014d). Two strains $(40 \%)$ were resistant to lincomycin, while all strains $(100 \%)$ were resistant to clindamycin. In a study that evaluated the use of NTCD strains for CDI prevention in hamsters, the three strains analyzed were susceptible to clindamycin (SAMBOL et al., 2002).

Lincosamides are used to treat infections caused by anaerobic microorganisms. The use of antimicrobials of this group is one of the main risk factors for developing CDI. In addition to the resistance of $\boldsymbol{C}$. difficile to lincosamides, these antimicrobials cause an imbalance of intestinal microbiota, affecting the pathogen's competitors (HUANG et al., 2010). The resistance of the $\boldsymbol{C}$. difficile strains evaluated in the present study to clindamycin is of utmost importance because this trait makes them able to compete with toxigenic strains in patients treated with clindamycin.

The tet $M$ gene was detected in the Z31 strain, which could explain the intermediate susceptibility profile of this strain to oxytetracycline by MIC. The simultaneous occurrence of the tet $M$ and erm $B$ genes, described as common by SPIGAGLIA (2007), was not observed in the present study. The bacitracin resistance genes ( $b c r A$ and $b c r B$ ) have never been described in $\boldsymbol{C}$. difficile and, different from what has been observed for $\boldsymbol{C}$. perfringens, these genes can be individually isolated in $\boldsymbol{C}$. difficile strains (CHARLEBOIS et al., 2012).

The main risk factor for CDI development in humans and equines is antimicrobial therapy, which causes an imbalance of the microbiota, favoring gastrointestinal tract colonization by $\boldsymbol{C}$. difficile (HUANG et al., 2010). Thus, the NTCD strain must have a high antimicrobial resistance profile to colonize the gastrointestinal tracts of patients subjected to antimicrobials to avoid colonization by toxigenic strains that have high antimicrobial resistance profiles due to the wide use of antimicrobials in veterinary practice (B̊̊VERUD et al., 2003; SILVA et al., 2014d).

Among the strains evaluated, those isolated from dogs were the ones with the highest spore production in vitro, mainly the $\mathrm{Z} 31$ strain. The H4 strain, which was isolated from swine, showed the lowest production (Table 1). In liquid culture medium in static conditions, concentrations exceeding $10^{6}$ spores $\mathrm{mL}^{-1}\left(>6 \log _{10}\right)$, such as those produced by the Z31 and R1 strains, are desirable. Considering the high dose suggested for CDI prevention in animals $\left(10^{7}\right.$ spores animal $\left.{ }^{-1}\right)$, a strain able to produce a high amount of spores is of utmost importance to facilitate the prevention of $\boldsymbol{C}$. difficile infection using a non-toxigenic strain (SILVA et al., 2014a). In other studies that use NTCD strains for CDI prevention in hamsters, there are no data on spore production by the evaluated strains (SAMBOL et al., 2002; NAGARO et al., 2013). Z31 and H4 strains showed the highest 
antimicrobial resistance profiles among the strains tested in the present study; however, the Z31 strains had the best spore production values; therefore, Z31 was selected for CDI prevention.

To evaluate the protective capacity of the NTCD strain, the Z31 strain was administered to hamsters. After 28 days, no animals died, no $\boldsymbol{C}$. difficile was isolated, no toxins were detected, and there were no histopathological lesions characteristic of the disease in the life control group (I). In contrast, animals of the death control groups (IV and V) challenged with the $\boldsymbol{C}$. difficile toxigenic strain died between 36 and $90 \mathrm{~h}$ after being challenged and exhibited hemorrhagic typhlitis. In these groups, the isolation of the toxigenic strain and toxin detection were possible from the day after the animals were challenged until death, confirming $\mathrm{CDI}$ as the classification of SILVA et al. (2014a). Hamsters in groups II and III, which received the NTCD strains, did not die, had no toxins detected in their intestinal contents, and exhibited no histological lesions. The toxigenic strain was isolated only one and two days after challenge but without the presence of toxins. SILVA et al. (2014a) observed the same results after animals not previously treated with antimicrobials were challenged with a toxigenic strain. The timely isolation with no detection of $\mathrm{A} / \mathrm{B}$ toxins and/or clinical signs suggest that the toxigenic strain simply passed through the gastrointestinal tract without colonizing it, possibly because the colonization sites were already occupied by the NTCD strain. Thus, there was no toxin production and, consequently, no disease was observed. The Mantel-Cox test revealed a significant difference between the survival curves of groups II and IV $(\mathrm{P}=0.0009)$ and groups III and $\mathrm{V}(\mathrm{P}=0.0011)$, indicating that the use of the NTCD strain was effective in preventing CDI in hamsters (Figure 2).

In the study conducted by SAMBOL et al. (2002) using an NTCD strain and challenging with three different toxigenic strains, the protection level ranged from 87 to $97 \%$. In contrast, NAGARO et al. (2013) managed to prevent the deaths of $100 \%$ of the hamsters when using two NTCD strains with the same goal. However, in both studies, only $10^{2}$ spores of the toxigenic strain were used in the challenge. The use of a larger amount of spores in the challenge is important because a high level of $\boldsymbol{C}$. difficile spore contamination is expected in the animal facilities (KEESSEN et al., 2011). The effectiveness of the NTCD strain in preventing CDI after being challenged with a large number of spores, as evaluated in the present study, places it as a strong candidate for CDI prevention when animal facilities are more contaminated (SILVA et al., 2013a).

The NTCD strain was isolated from one day post-inoculation until the end of the experiment from all animals that received its inoculum and was detected by electron microscopy (Figure 3 ). The presence of the NTCD strain for long periods

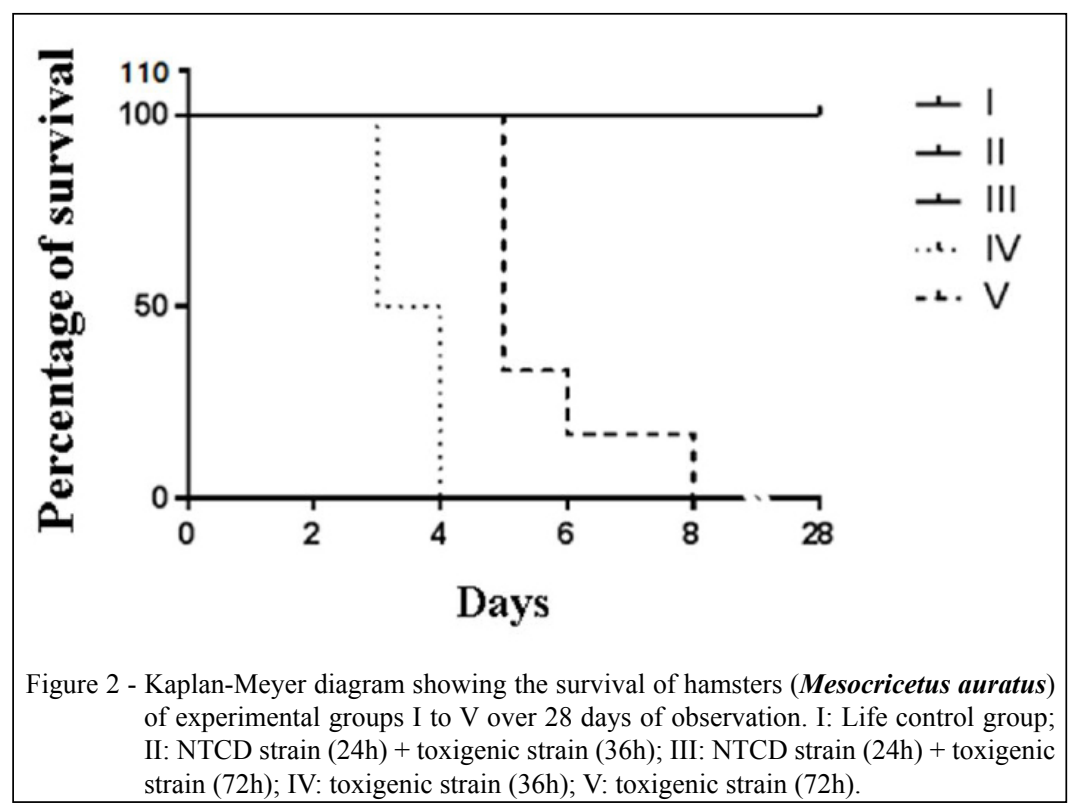

Ciência Rural, v.46, n.5, mai, 2016. 


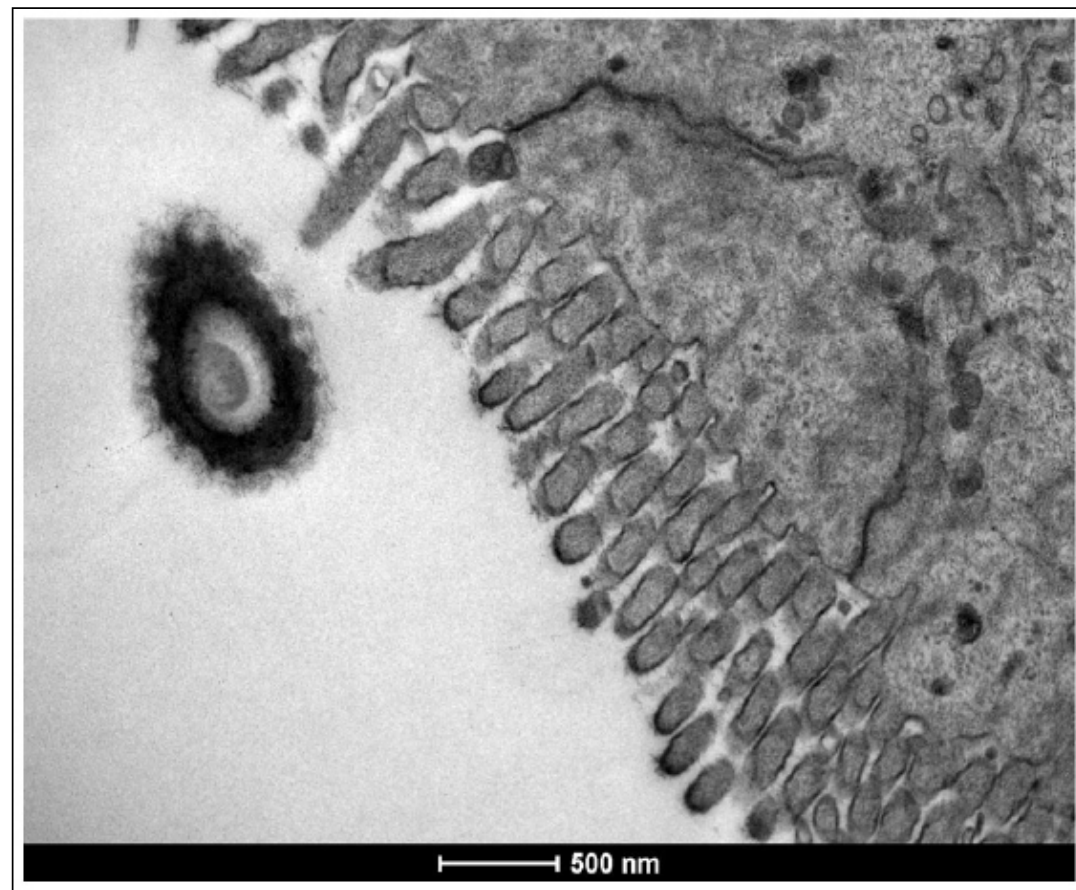

Figure 3 - Electron micrograph of intestinal villi of a hamster's colon (Mesocricetus auratus) from group III. The spore is an oval structure with a central nucleus and an electrodense capsule close to intact villi of an animal that was isolated the NTCD strain.

has been demonstrated in other studies (SAMBOL et al., 2002; NAGARO et al., 2013) and may be useful for preventing a recurrent infection as, in case of decreased microbiota, the NTCD strain would multiply, preventing colonization by the toxigenic strain (VILLANO et al., 2012). In animal production, in particular pig farming, strain maintenance in the intestinal tract for a long period would lead to dissemination of the strain in the animal facilities. It is believed that over time, there would be a natural intake of NTCD strains by animals, which would contribute to decreased incidence of the disease, even without active and constant administration of the NTCD strain (SONGER et al., 2007).

The use of NTCD strains to prevent CDI has already been used in other species with relative success. SONGER et al. (2007) observed that the detection of $\mathrm{A} / \mathrm{B}$ toxins in piglets that received the NTCD strain orally was $12 \%$ lower than in the control group. In humans, the first stage of a study with the NTCD strain demonstrated that it is able to colonize the gastrointestinal tracts of patients whose microbiota were affected by the use of antimicrobials, which is the main risk factor for CDI occurrence (VILLANO et al., 2012). The present study consolidates the selection of a strain isolated in Brazil that may ultimately be tested for CDI prevention in several species.

\section{CONCLUSION}

The strain NTCD Z31 showed the highest spore production in vitro, the higher antimicrobial resistance profile and was effective in preventing CDI in $100 \%$ of the hamsters. These results indicate this strain as a strong candidate for the prevention of the disease in the target species as swine, for example.

\section{BIOETHICS AND BIOSSECURITY COMMITTEE APPROVAL}

The present study was approved by the Ethics Committee under the protocol number 13/2014 CEUA-UFMG.

\section{ACKNOWLEDGMENTS}

Fundação de Amparo à Pesquisa do estado de Minas Gerais (FAPEMIG), Coordenação de Aperfeiçoamento de Pessoal de Nível Superior (CAPES), Conselho Nacional de Desenvolvimento Científico e Tecnológico (CNPq) and PróReitoria de Pesquisa da Universidade Federal de Minas Gerais (PRPq-UFMG). 


\section{REFERENCES}

BÅVERUD, V. et al. Clostridium difficile: prevalence in horses and environment, and antimicrobial susceptibility. Equine Veterinary Journal, v.35, n.5, p.465-471, 2003. Available from: $<$ http://www. ncbi.nlm.nih.gov/pubmed/12875324>. Accessed: Jan. 30, 2015.

CLSI (CLINICAL AND LABORATORY STANDARDS INSTITUTE). Performance standards for Antimicrobial Susceptibility Test. Twenty-first Information Supplement, v.31, n.1, January, 2011.

CHARLEBOIS, A. et al. Characterization of genes encoding for acquired bacitracin resistance in Clostridium perfringens. Plos One, v.7, n.9, p.1-9, 2012.

CRUZ JUNIOR, E.C. et al. A surveillance of enteropathogens in piglets from birth to seven days of age in Brazil. Pesquisa Veterinária Brasileira, v.33, n.8, p.963-969, 2013.

HUANG, H. et al. Antimicrobial susceptibility and heteroresistance in Chinese Clostridium difficile strains. Anaerobe, v.16, n.6, p.633-635, 2010.

HUMPHREY, C.D. et al. Light and electron microscopic studies of antibiotic associated colitis in the hamster. Gut, v.20, p.6-15, 1979.

JANEZIC S.; RUPNIK M. Molecular typing methods for Clostridium difficile: pulsed-field gel electrophoresis and PCR ribotyping. Methods in Molecular Biology, v.646, p.5565, 2010. Available from: <http://www.ncbi.nlm.nih.gov/ pubmed/20597002>. Accessed: Jan. 30, 2015.

JANEZIC, S. et al. Clostridium difficile genotypes other than ribotype 078 that are prevalent among human, animal and environmental isolates. BMC Microbiology, v.12, p.4855, 2012. Available from: <http://www.ncbi.nlm.nih.gov/ pubmed/22452857>. Accessed: Jan. 30, 2015.

KEEL, K. et al. Prevalence of PCR ribotypes among Clostridium difficile from pigs, calves, and other species. Journal of Clinical Microbiology, v.45, n.6, p.1963-1964, 2007.

KEESSEN, E.C. et al. Aerial dissemination of Clostridium difficile on a pig farm and its environment. Environmental Research, v.111. n. 8, p.1027-1032, 2011.

KILLGORE, G. et al. Comparison of seven techniques for 22 typing international epidemic strains of Clostridium difficile: restriction endonuclease analysis, 23 pulsed-field gel electrophoresis, PCRribotyping, multilocus sequence typing, multilocus 24 variable-number tandem-repeat analysis, amplified fragment length polymorphism, and surface 25 layer protein A gene sequence typing. Journal of Clinical Microbiology, v.46, n.2, p.431-437, 2008. Avaiable from: <http:// jcm.asm.org/content/46/2/431>. Acessed: Jan. 30, 2015.

KOENE, M.G. et al. Clostridium difficile in Dutch animals their presence, characteristics and similarities with human isolates. Clinical Microbiology and Infection, v.18, n.8, p.778-784, 2011. Available from: <http://www.ncbi.nlm.nih.gov/pubmed/21919997>. Acessed: Jan. 30, 2015. doi: 10.1111/j.1469-0691.2011.03651.x.

MERRIGAN M.M. et al. New approach to the management of Clostridium difficile infection: colonisation with non-toxigenic $\boldsymbol{C}$. difficile during daily ampicillin or ceftriaxone administration. International Journal of Antimicrobial Agents, v.33, n.1, p.46-50, 2009.
NAGARO, K.J. et al. Nontoxigenic Clostridium difficile protects hamsters against challenge with historic and epidemic strains of toxigenic BI/NAP1/027 C. difficile. Antimicrobial Agents and Chemotherapy, v.57, n.11, p.5266-5270, 2013. Available from: $<$ http://www.ncbi.nlm.nih.gov/pubmed/23939887>. Acessed: Jan. 30, 2015. doi: 10.1128/AAC.00580-13.

SAMBOL, S.P. et al. Colonization for the prevention of Clostridium difficile disease in hamsters. Journal of Infectious Diseases, v.186, n.12, p.1781-1789, 2002.

SILVA, R.O.S. et al. Detection of toxins $\mathrm{A} / \mathrm{B}$ and isolation of Clostridium difficile from piglets in Brazil. Ciência Rural, v.41, n.8, p.1130-1135, 2011.

SILVA, R.O.S. et al. Clostridium difficile infection: main features and occurrence in domestic species in Brazil. Ciência Rural, v.43, n.1, p.73-80, 2013a.

SILVA, R.O.S. et al. Detection of A/B toxin and isolation of Clostridium difficile and Clostridium perfringens from foals. Equine Veterinary Journal, v.45, n.6, p.671-675, 2013b. Available from: <http://www. ncbi.nlm.nih.gov/pubmed/23452044>. Accessed: Jan. 30, 2015.

SILVA, R.O.S. et al. Padronização de um modelo de infecção de Clostridium difficile em hamsters sírios Mesocricetus auratus. Ciência Rural, v.44, n.8, p.1415-1421, 2014a.

SILVA, R.O.S. et al. Carriage of Clostridium difficile in freeliving South American coati (Nasua nasua) in Brazil. Anaerobe, v.30C, p. $99-19$ 101, $2014 b$.

SILVA, R.O.S. et al. Clostridium difficile and Clostridium perfringens from wild carnivore species in Brazil. Anaerobe, v.28, p.207-211, 2014c. Available from: <http://www.ncbi.nlm.nih. gov/pubmed/24979683>. Accessed: jan. 30, 2015. doi:10.1016/j. anaerobe.2014.06.012.

SILVA, R.O.S. et al. Antimicrobial susceptibility of Clostridium difficile isolated from animals and humans in Brazil. Ciência Rural, v.44, p.841-846, 2014d.

SONGER, J.G.; ANDERSON, M.A. Clostridium difficile: an important pathogen of food animals. Anaerobe, v.12, n.1, p.1-4, 2006. Available from: <http://www.ncbi.nlm.nih.gov/pubmed/16701605>. Accessed: jan. 30, 2015. doi: 10.1016/j.anaerobe.2005.09.001.

SONGER, J.G. et al. Prevention of porcine Clostridium difficileassociated disease by competitive exclusion with nontoxigenic organisms. Veterinary Microbioogy, v.124, p.358-361, 2007. Available from: $<$ http://www.ncbi.nlm.nih.gov/pubmed/17493774> Acessed: jan. 30, 2015. doi:10.1016/j.vetmic.2007.04.019.

SPIGAGLIA, P. et al. Detection of a genetic linkage between genes coding for resistance to tetracycline and erythromycin in Clostridium difficile. Microbial Drug Resistance, v.13, n.2, p.90-95, 2007. Available from: <http://www.ncbi.nlm.nih. gov/pubmed/17650959>. Acessed: jan. 30, 2015. doi: 10.1089/ mdr.2007.723.

VILLANO, S.A. et al. Evaluation of an oral suspension of VP20621, spores of nontoxigenic Clostridium difficile strain M3, in healthy subjects. Antimicrobial Agents and Chemotherapy, v.56, n.10, p.5224-5229, 2012. Available from: <http://www.ncbi. nlm.nih.gov/pubmed/22850511>. Acessed: jan. 30, 2015. doi: 10.1128/AAC.00913-12. 